\title{
Ligand Binding Domain
}

National Cancer Institute

\section{Source}

National Cancer Institute. Ligand Binding Domain. NCI Thesaurus. Code C13671.

A Binding Site Domain is a region of protein that physically interacts stereospecifically, and usually at high affinity, with a specific ligand, substrate, or a specific domain of some complex target biomolecule, such as a protein, lipid, carbohydrate, or nucleic acid.

Typically, but not necessarily, the interaction results in protein conformational alteration and functional modification. 